\title{
АРХЕОЛОШКИ ЛОКАЛИТЕТ ШЕТАЋЕ НА МАЛОМ ВУКАНУ У ГОРЊАЧКОЈ КЛИСУРИ
}

\author{
Милан Б. Миловановић \\ Пожаревац \\ Иван Р. Марјановић \\ Пожаревац
}

\begin{tabular}{r|c} 
e-mail: mimidusanovac@gmail.com & Прегледни рад \\
Примљено: 25.4.2020. & УДК: 904:711.559.6(497.11)”18” \\
Прихваћено: 23.6.2020. & $902.2(497.11)$
\end{tabular}

\begin{abstract}
Апстракт: Октобра 2019. године аутори овог рада обишли су археолошки локалитет Шетаће на Малом Вукану у Горњачкој клисури изнад десне обале Млаве. На овом месту данас се распознају добро видљиви остаци утврђења и рова. Судећи према досадашњим истраживањима Горњачке клисуре и њене шире околине, локалитету Шетаће је у науци посвећена мала пажња. У раду је представљено данашње стање археолошког налазишта како би се указало на могуће правие даљег истраживања. Поред тога, дат је и краћи осврт на поједине одбрамбене зидине које се налазе у ареалу Горњачке клисуре.
\end{abstract}

Кључне речи: Горњачка клисура, Шетаће, Мали Вукан, одбрамбени зид, Ждрело, утврђење

\section{Увод}

Остаци фортификација у Горњачкој клисури, која се налази на 14 км југоисточно од Петровца на Млави (сл. 1), нису у великој мери били предмет стручних проучавања у археологији. Стога, судећи према случајно сакупљеним налазима, ареал Горњачке клисуре је првобитно био насељен у бакарном и бронзаном добу (Стојић и Јацановић 2008, 357), а коришћен је и током халштатског периода (Мадас и Гајић 1983, 221-222, нап. 1). Одређен број случајних налаза указује на присуство становништва и током римског, као и касноантичког раздобља, али они су до данас објављени у мањој мери (Цуњак и Миљковић 1992, 102; Миловановић 2016а, 213; Milovanović 2019). У стручној јавности преовладава мишљење да се у Горњачкој клисури налазе остаци средњовековног Ждрела (Динић 1958, 17-18; Вушковић 2008; Вушковић 2010, 107-108), које у српским писаним изворима први пут спомиње архиепископ Данило II (1324-1337) (Даничић 1866, 115; Мак Даниел 1991, 220). Видљиви остаци фортификација данас се добро распознају 


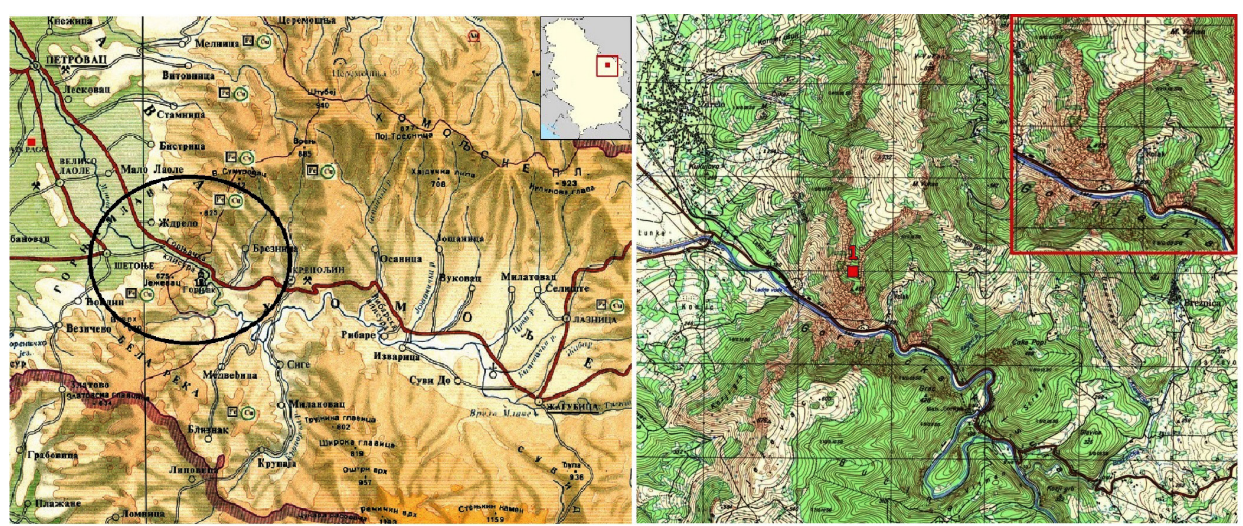

Сл. 1. Географски положај Горњачке клисуре у Хомољу и локалитета Шетаће

Fig. 1. Geographical location of the Gornjačka Klisura gorge in Homolje and the site of Šetaće

изнад леве и десне обале Млаве. Реч је о читавом низу кула и бедема на којима нису спроведена стручна археолошка ископавања (Миловановић у штампи). Од одбрамбених целина на десној обали реке, у Горњачкој клисури, издвајају се локалитети Јеринина кула, испод које се по вертикали налази тврђава Узенгије, као и локалитет Стража - Чока попи прекопута манастира Горњак. На супротној страни Млаве, на врховима и обронцима Јежевца, као и на самом улазу у клисуру, такође су евидентирани остаци кула и бедема (Цуњак и Миљковић 1992, 101; Јацановић и Живковић 2000, 121, 147, Т. VII; Milovanović 2019). Осим наведених фортификација, на простору Горњачке клисуре се налази и локалитет Шетаће на Малом Вукану, са остацима војне архитектуре. Његов назив представља искварену варијанту румунског термина cetate, која означава град-тврђаву (Flora 1952, 74). Током октобра 2019. године аутори овог текста обишли су локалитет и том приликом сакупили значајне податке, који ће бити представљени у овом раду. ${ }^{1}$

\section{Историјат истраживања}

Комплекс фортификација у Горњачкој клисури, који се налази на обронцима Малог Вукана и Јежевца, био је незаобилазан у очима страних и домаћих путописаца током 19. века (Миловановић у штампи). Прве податке о некадашњим градовима у Горњачкој клисури добијамо од пруског официра Ота Фердинанда Дубисава Пирха (Пирх 1900, 101). Током друге

\footnotetext{
${ }^{1}$ Осим локалитета Шетаће, извршен је и обилазак остатака фортификација на локалитетима Јеринина кула и Узенгије изнад десне обале Млаве.
} 
трећине 19. столећа, одбрамбене зидине у клисури Млаве обилазе учитељ Тодор Влаић и професор Јосиф Веселић (Влаић 1850, 32-35; Веселић 1867 , 119-120, 126). Ипак, треба напоменути да се у њиховим белешкама не наилази на топониме, тако да не можемо са сигурношћу рећи да ли су они обишли и локалитет који је тема овог рада.

Током друге половине 19. века, намерници који су пролазили овим крајем оставиће значајне податке о фортификацијама изнад леве и десне обале Млаве. Потес Шетаће међу првима обилазе лицејски питомци из Београда. Ако се пажљиво сагледају белешке које су саставили, као и њихово кретање по десној страни Горњачке клисуре, може се закључити да је експедиција остатке зидина испод Малог Вукана обишла 9. јула 1863. године. У дневнику je, између осталог записано: „На само подне били смо на врх Вукана [...]. Ми смо сад били на једном заравњу који је био за 2300 стопа над морском површином и чије су стене у ждрелском теснацу градиле као некакав амфитеатар. Баш смо били више 'митрополије'. Чудно изгледаху с висине те развалине које озида ондашња побожност [...]. После много хода и обилазења седнемо да се одморимо испод једне старе татарске зидине. Беше се на места од њених платна одржало за два и три човечија боја. Била је сазидна баш на врх једног крша. Са истока и југа била је над пропасти јер ту су се стене спуштале сасвим одвесно за неколико стотина стопа. Са севера и запада беше град ограђен некаквим шанцем. У дужину беше за једно 15 а у ширину за 8 хвата" (Поповић 1867, 39-41).

Наредно интересовање за остатке зидина на Малом Вукану забележено је почетком седамдесетих година 19. века. Тада је професор војне географије на Артиљеријској школи у Београду, Јован Драгашевић, вршио испитивања планина и долина у Хомољу. Поред природно-географских карактеристика, у његовим белешкама можемо пронаћи податке и о старинама овог дела Браничева. Резултате својих истраживања објавио је 1876. године. Приликом проучавања Малог Вукана запазио је остатке градића за који је сматрао да припада средњем веку (Драгашевић 1876, 312-313). Он такође оставља и скицу овог планинског врха, на којој је, у делу према Млави, нацртао хексагоналну основу (сл. 2). Унутар хексагоналног простора уочава се један преломљен крак, а у самом средишту уписана је ознака која подсећа на ћирилично мало писано слово „Г”, које највероватније означава термин „градић”.

Остаци „градића” на Вукану такође су поменути у делу Кнежевина Србија из 1876. године (Милићевић 1876, 1032), док идентичан податак можемо пронаћи у књизи Србија-опис земље народа и државе из 1887. године 


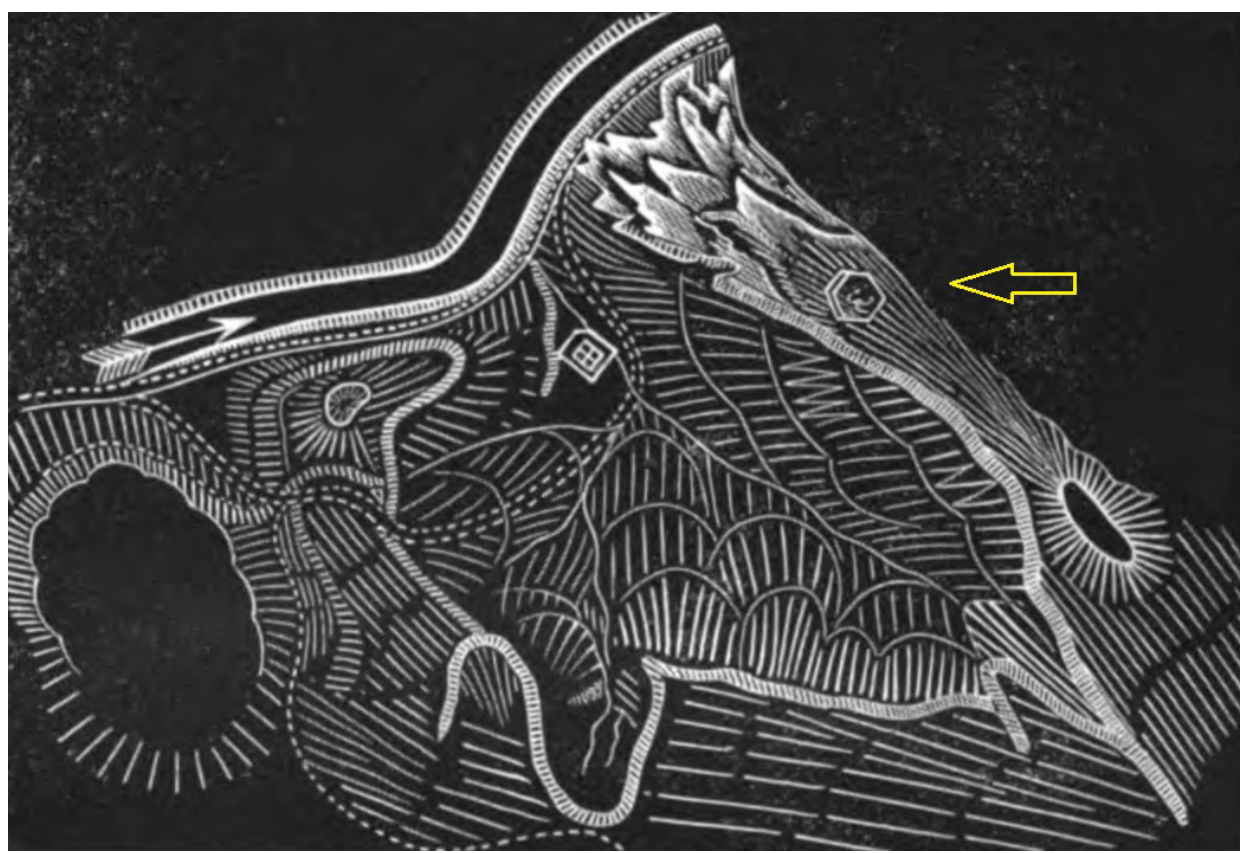

Сл. 2. Положај утврђења испод Малог Вукана према Јовану Драгашевићу (Драгашевић 1876, 312)

Fig. 2. The position of the fort below Mali Vukan according to Jovan Dragašević (Драгашевић 1876, 312)

(Карић 1887, 849). Под именом Шетаће, локалитет се први пут у литератури јавља код антропогеографа Љубомира Јовановића 1903. године (Јовановић 1903, 11, 385-386). Лета 1947. године први пут је нека научна институција обишла Горњачку клисуру. Тада је Ђурђе Бошковић обишао остатке фортификација на Узенгијама изнад Млаве, као и сакралне споменике (Митрополија, Благовешетње и Горњак). Међутим, у извештају се спомиње и „доста добро очувани део града који се по казивању налази испод Вукана", али због невремена и даљине није био испитан (Бошковић 1950, 187-190).

Најзначајније податке о остацима архитектуре на локалитету Шетаће у Горњачкој клисури забележио је Никола Крстић током педесетих година прошлог века. По струци је био учитељ и наставник физичког васпитања у Петровцу на Млави, а по сензибилитету љубитељ старина. Поред тога, био је један од значајнијих сарадника Пожаревачког музеја (Јацановић и Живковић 2000, 111, 121-122; Dragojević 1983, 55). Остаци зидина у Горњачкој клисури били су главни предмет интересовања Николе Крстића, а иза њега су остали многобројни цртежи, записане легенде, као и друге белешке у ко- 


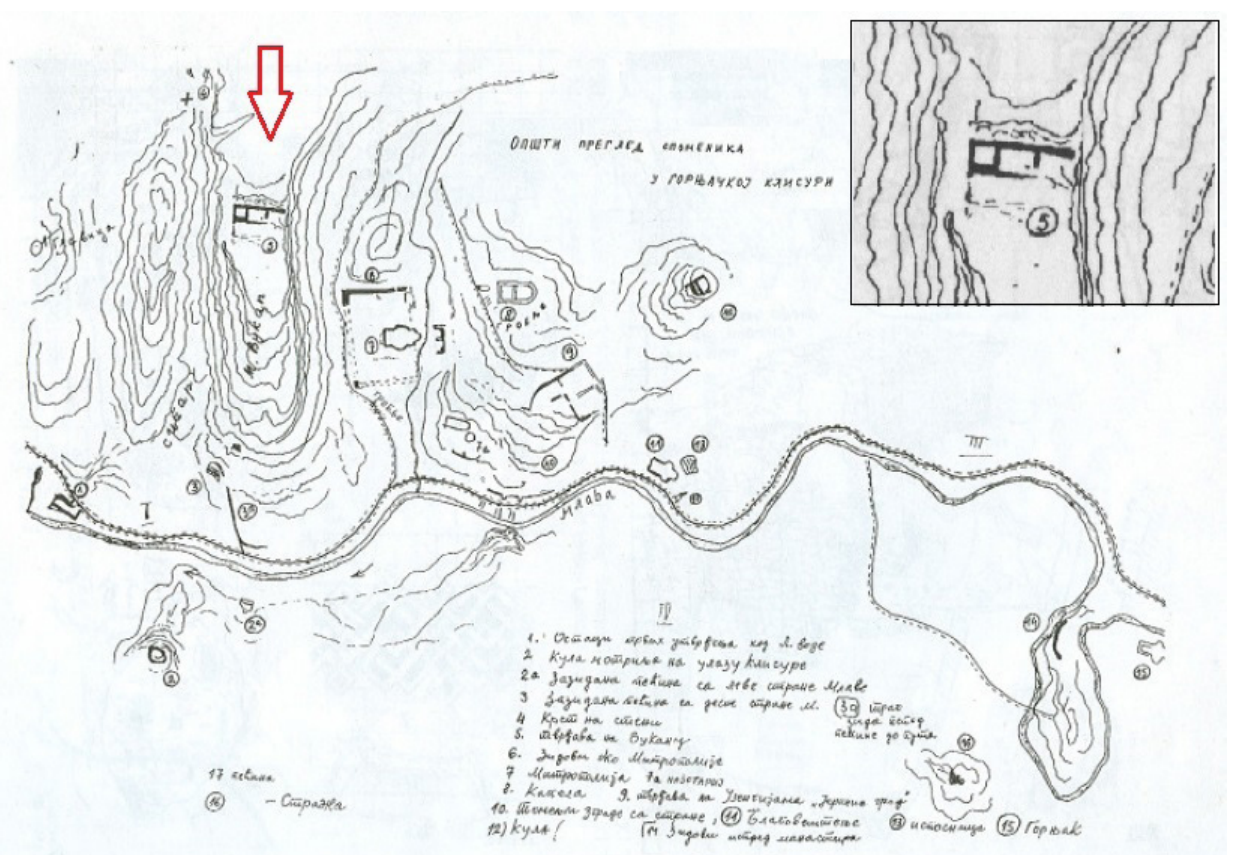

Сл. 3. Скица археолошких налазишта у Горњачкој клисури према Н. Крстићу (прир. Јацановић и Живковић 2000: 147, Т. VII)

Fig. 3. Sketch of archaeological sites in the Gornjačka Klisura gorge according to N. Krstić (ed. Јацановић и Живковић 2000: 147, T. VII)

јима се могу пронаћи драгоцени подаци о степену очуваности археолошких налазишта и црквених споменика унутар поменутог простора. Најзначајнија је свакако његова скица Горњачке клисуре (сл. 3), на којој се могу видети положаји фортификација и сакралних објеката које је он обишао током својих „испитивања”. Судећи према достављеној основи, уз северни и јужни зид подигнуте су две четвороугаоне грађевине. На приложеној основи се такође назире и јужни зид утврђења. Осим тога, начинио је и цртеж бедема, на коме се распознаје степен његове очуваности (сл. 4).

Утврђење на Малом Вукану позиционирано је и на карти коју су направили Димитрије Мадас и Александар Гајић 1983. године. На њој су убицирани и остаци других фортификација, попут оних на врховима Узенгије и Јеринина кула на десној обали Млаве, као и њихови остаци на Јежевцу (врх Досу Мик?) на левој (Мадас и Гајић 1983, 240; Мадас 1997, 313, Карта 1). Локалитет Шетаће био је предмет интересовања Млађана Цуњака (Регионални завод за заштиту споменика културе из Смедерева) и Милорада Миљ- 


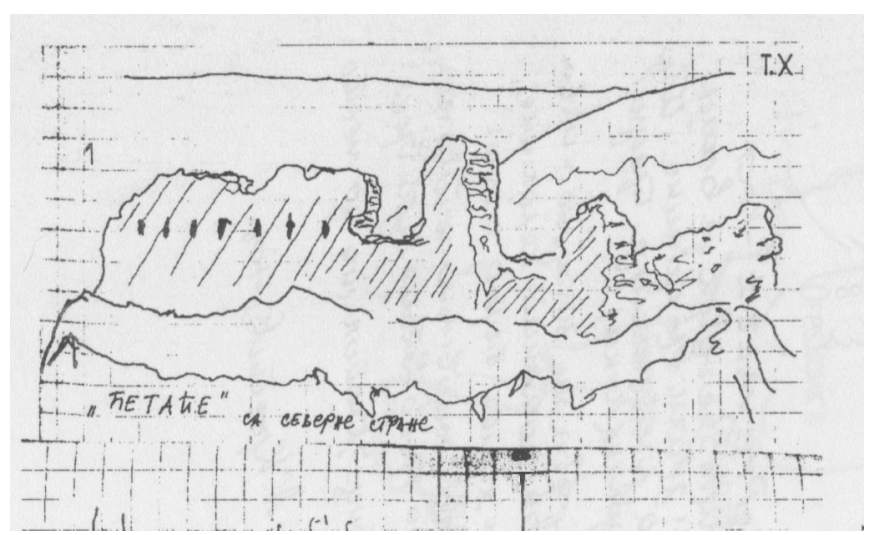

Сл. 4. Цртеж северног зида утврђења на локалитету Шетаће према Н. Крстићу (прир. Јацановић и Живковић 2000: 149, Т. X/1)

Fig. 4. Drawing of the northern wall of the fort at the site of Šetaće according to N. Krstić (ed. Јацановић и Живковић 2000: 149, Т. Х/1)

ковића (Републички завод за заштиту споменика културе из Београда) током арехолошких рекогносцирања Горњачке клисуре 1992. године. У краћем извештају се наводи да је реч о правоугаоном утврђењу које има „зидове у висини до 2 м са видним рупама у зиду за греде тавањаче" (Цуњак и Миљковић 1992, 101). Последњих неколико година дошло се до нових сазнања о фортификацијама на левој и десној обали Млаве у Горњачкој клисури (Миловановић 2016а, 115-119; Миловановић 2016б, 16-20;² Миловановић 2017, 33; Milovanović 2019; Миловановић у штампи).

\section{Положај локалитета и географско окружење}

У географском смислу Горњачка клисура се налази у западном делу хомољске микрорегије. Она се састоји од кречњачких планинских врхова Великог (825 м) и Малог Вукана (732 м) на северу, и Јежевца (675 м) на југу, који су у саставу Хомољских планина (940 м). Кроз клисуру протиче река Млава, која низводно, између села Шетоња и Ждрела, пресеца плодну стишку равницу. Узводно од реке, простире се Рибарска клисура, која заједно са Горњачком чини укупну дужину од 24 км (Марковић 1988, 76, 81, 150; Петковић 1935, 39-42; Milovanović 2019, 55).

Остаци зидина на археолошком налазишту Шетаће изграђени су испод планинског врха Мали Вукан на 479 м надморске висине, у јужном делу планинског масива, на десној обали Млаве (сл. 5). Положај утврђења

${ }^{2}$ Из рада који је проистекао поводом звања кустоса 2016. године у Народном музеју у Београду. 


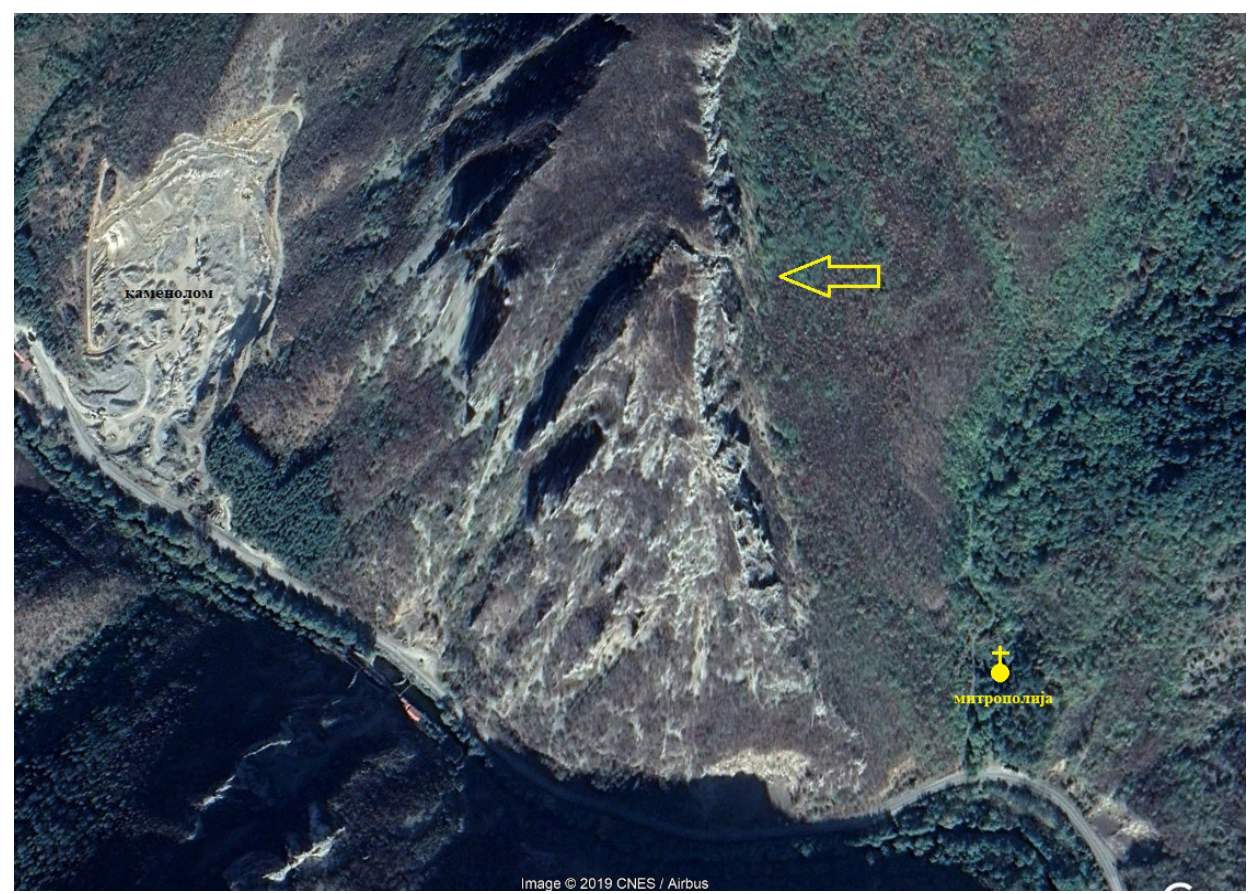

Сл. 5. Положај археолошког локалитета Шетаће на мапи Google Earth

Fig. 5. Location of the archaeological site of Šetaće on the Google Earth map

је вешто одабран будући да је контролисао улаз у стишку равницу. Важно је поменути да су са врха Малог Вукана, у правцу истока, видиљиви остаци фортификација на локалитетима Јеринина кула и Узенгије, изнад десне обале Млаве (сл. 6). У истом правцу, нешто даље, налазе се утврђене позиције у Горњачкој клисури и унутрашњости Хомоља: Грац - Горњачки извор, Стража - Чока попи, Градац код Крепољина, Пчелињи крш у Лазници и Потај чука на путу према Бору. ${ }^{3}$ У близини локалитета Шетаће, поред пута Петровац-Жагубица налази се активан каменолом који прети да уништи његову ближу околину.

У непосредној близини локалитета Шетаће регистровани су трагови рударења, који су потврђени у неколико наврата током 19. века у долини реке (О)Решковице (Хердер 1845, 3; Милићевић 1876, 1031; Јовановић 1903, 386). У питању је река која протиче кроз клисуру коју чине северни

\footnotetext{
3 У питању су археолошка налазишта која су била насељена у праисторији и током 4-6. века (Миловановић и Филиповић 2018; Миловановић 2018; Milovanović 2019). Међу њима се једино издваја локалитет Градац код Крепољина на левој обали Млаве, за који се сматра да је коришћен и током средњег века (Цуњак и Миљковић 1993; Milovanović, Radisavljević and Filipović in print).
} 


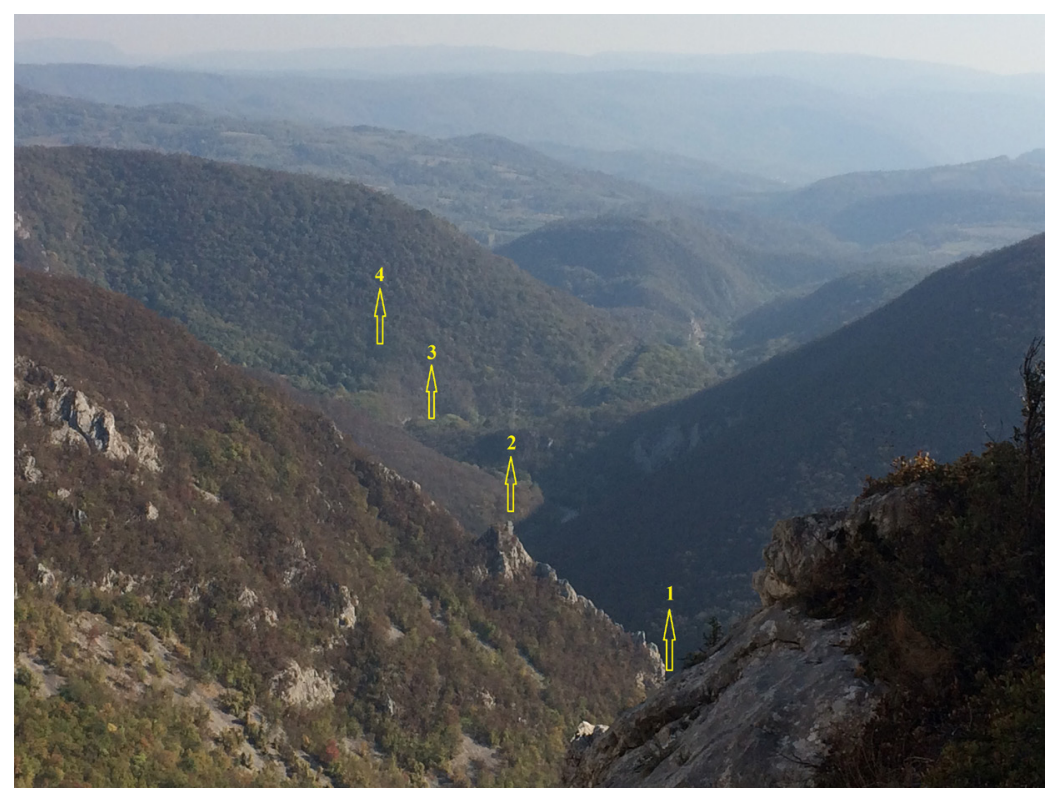

Сл. 6. Поглед према утврђењима Горњачке клисуре са локалитета Шетаће:

1. Узенгије; 2. Јеринина кула; 3. Грац - Горњачки извор; 4. Стража - Чока попи (фото: М. Миловановић и И. Марјановић)

Fig. 6. View towards the forts in the Gornjačka Klisura gorge from the site of Šetaće: 1. Uzengije; 2. Jerina's Tower; 3. Grac - the spring of Gornjački Izvor; 4. Straža - Čoka Popi (photo: M. Milovanović and I. Marjanović)

обронци Великог Вукана и врх Лукин камен. На основу резултата каснијих истраживања утврђени су трагови рударења од праисторије до средњег века (Мркобрад 1997, 156-157), који се односе првенствено на експлоатацију бакра и олова са златом и сребром (Simić 1951, 249), док је руда цинка заступљена у мањим количинама. На основу хемијске анализе шљаке која је ту пронађена утврђено је да у основној гвозденој руди постоје примесе бакра и олова (Мркобрад 1997, 156-157; Јовић 1997, 23-24). Трагови рударења такође су установљени и код села Мелнице (Мркобрад 1997, 156), као и у мајдану у Кучајни, који се налазио око 18 км северно од Малог Вукана. Сматра се да је и овде експлоатисана разноврсна руда, са прекидима, од праисторије па све до прве половине 20. века (Simić 1951, 243-247; Мирковић 1981, 87; Ћирковић, Ковачевић-Којић и Ћук 2002, 13, 53, 189; Јовић 1997, 24; Мркобрад $1997,152,156)$. Сведочанство о рударским активностима пружају и топоними у ближој околини Малог Вукана, као што су „Мајдан” и „Рудина” ${ }^{4}$

${ }^{4}$ Вид. Izdanje і štampa Vojnogeografski institut, Br. evidencije 007095, Žagubica 1-3 (Krepoljin), $\mathrm{R}=1: 25000$, Drugo izdanje-štampano 1971. g. 
Изнето је мишљење да је током античког периода кроз клисуру водила саобраћајница ка Гамзиграду (Цуњак и Миљковић 1992, 103; Цуњак и Миљковић 1993, 67). На основу тога се може претпоставити да се горњомезијски римски пут, који је у науци познат као Via Militaris (Узелац 2018, 12), одвајао код Јовис Пага (Iovis Pago), чији се остаци налазе у селу Велико Лаоле код Петровца. У том случају би један крак ишао према Хореум Маргију (Horreum Margi) и Наисусу (Naissus) (Vasić i Milošević 2000, 139; Јиречек $1959,113)$, а други би се правац, преко Горњачке клисуре и Хомоља, усмеравао ка унутрашњости провинције Приобалне Дакије (Dacia Ripensis). Може се са великом сигурношћу претпоставити да је овај римски пут коришћен и током средњег века, као што је то случај са путем који је ишао десном долином Велике Мораве (Шкриванић 1974, 117-118; Благојевић 1987, 108; Ћирковић 1981, 466; Узелац 2015, 19; Milovanović, Radisavljević and Filipović in print).

\section{Локалитет Шетаће - данашње стање на терену}

У овом делу Хомољских планина налази се велика увала у облику амфитеатра (Поповић 1867, 40). Овај простор омеђен је врховима Малог Вукана, падином Стрмне пољане, локалитетима Јеринином кулом и Узенгијама, и Млавом. Утврђење испод Малог Вукана саграђено је на стеновитом платоу неправилне трапезоидне основе површине око 0,60 ха (сл. 7). Терен је у овом делу масива искошен где се горња, северна страна постепено спушта према јужним оштрим литицима, односно Млави (сл. 8). Са источне стране простире се вертикална непроходна литица испод које су видљиви остаци Митрополије.

Испод западног зида утврђења, простире се уска, стрма падина и спушта се до Млаве, која се налази на коти нижој око 300 м него локалитет. Падина је окружена ретком шумом и високим стенама, а њену површину чини сипар, који се састоји од кречњачког камена мале и средње величне. Силазећи низ падину, пролази се поред тзв. Велике пећине, испред чијег улаза је подигнут зид (Цуњак и Миљковић 1992, 102).

На северној страни локалитета Шетаће, изграђен је одбрамбени зид испод којег се налази усек у стени, односно ров (сл. 9, 10). Даље према северу протеже се успон који води до највише висинске тачке на Малом Вукану. Између овог врха и Великог Вукана налази се планински превој (тзв. седло). Прилаз локалитету могућ је управо са ове стране. До утврђења се најлакше стиже када се, поред Митрополије, правац кретања усмери према североисточним, нешто блажим падинама Малог Вукана. У овом делу налази се 


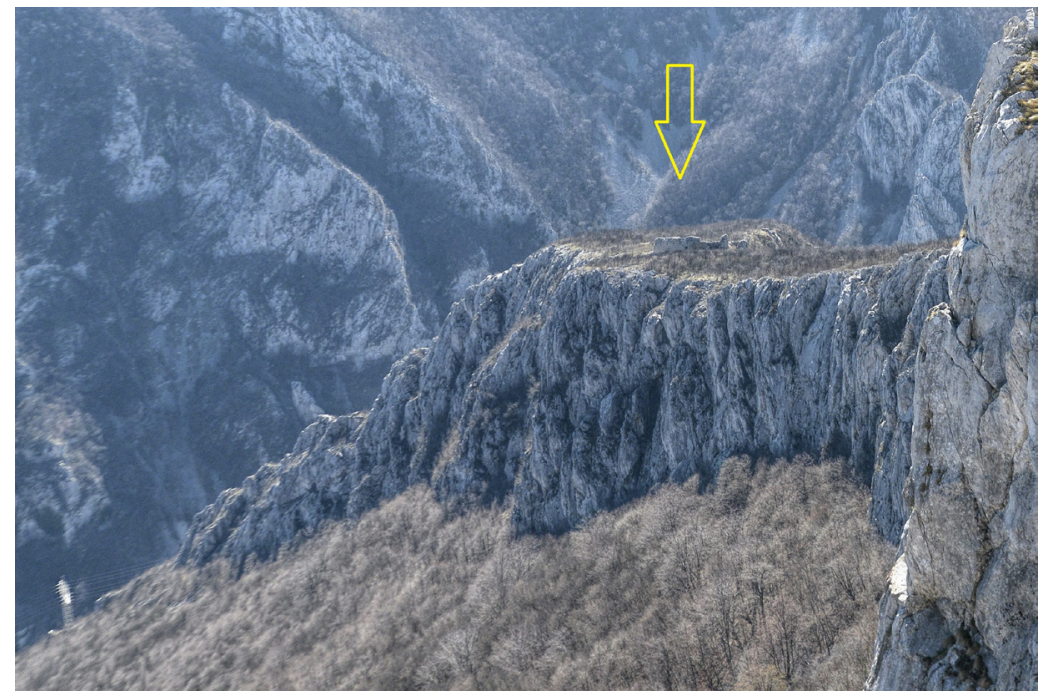

Сл. 7. Остаци утврђења на локалитету Шетаће, поглед са Малог Вукана (фото: Б. Траиловић)

Fig. 7. Remains of the fort at the site of Šetaće, view from Mali Vukan (photo: B. Trailović)

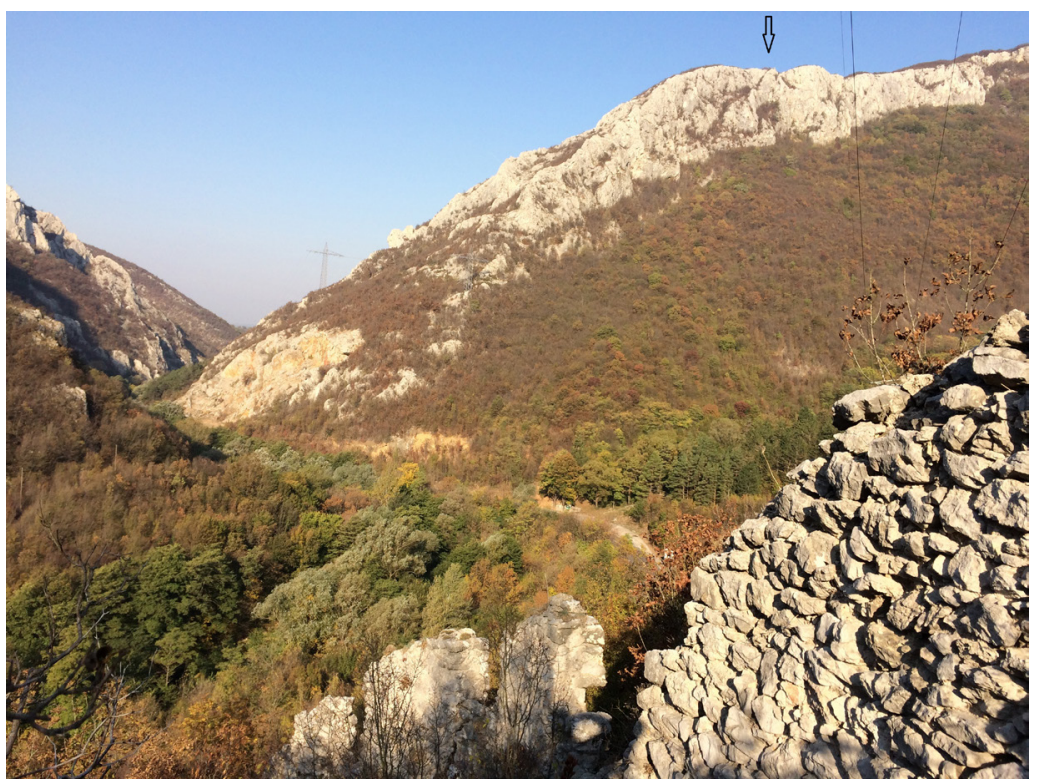

Сл. 8. Поглед на локалитет Шетаће са утврђења Узенгије (фото: М. Миловановић и И. Марјановић)

Fig. 8. View of the site of Šetaće from the fort of Uzengije (photo: M. Milovanović and I. Marjanović) 


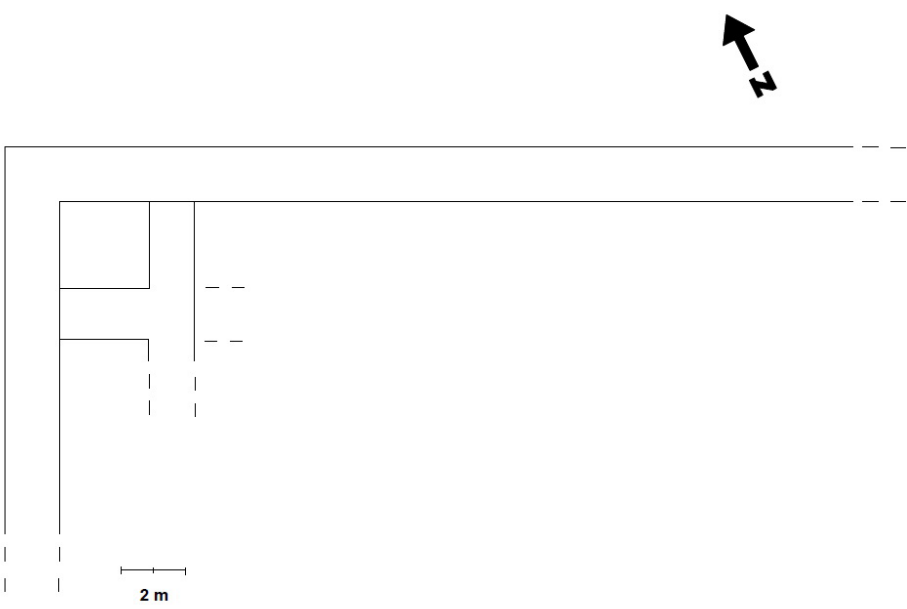

Сл. 9. Основа утврђења на локалитету Шетаће

Fig. 9. The base of the fort at the site of Šetaće

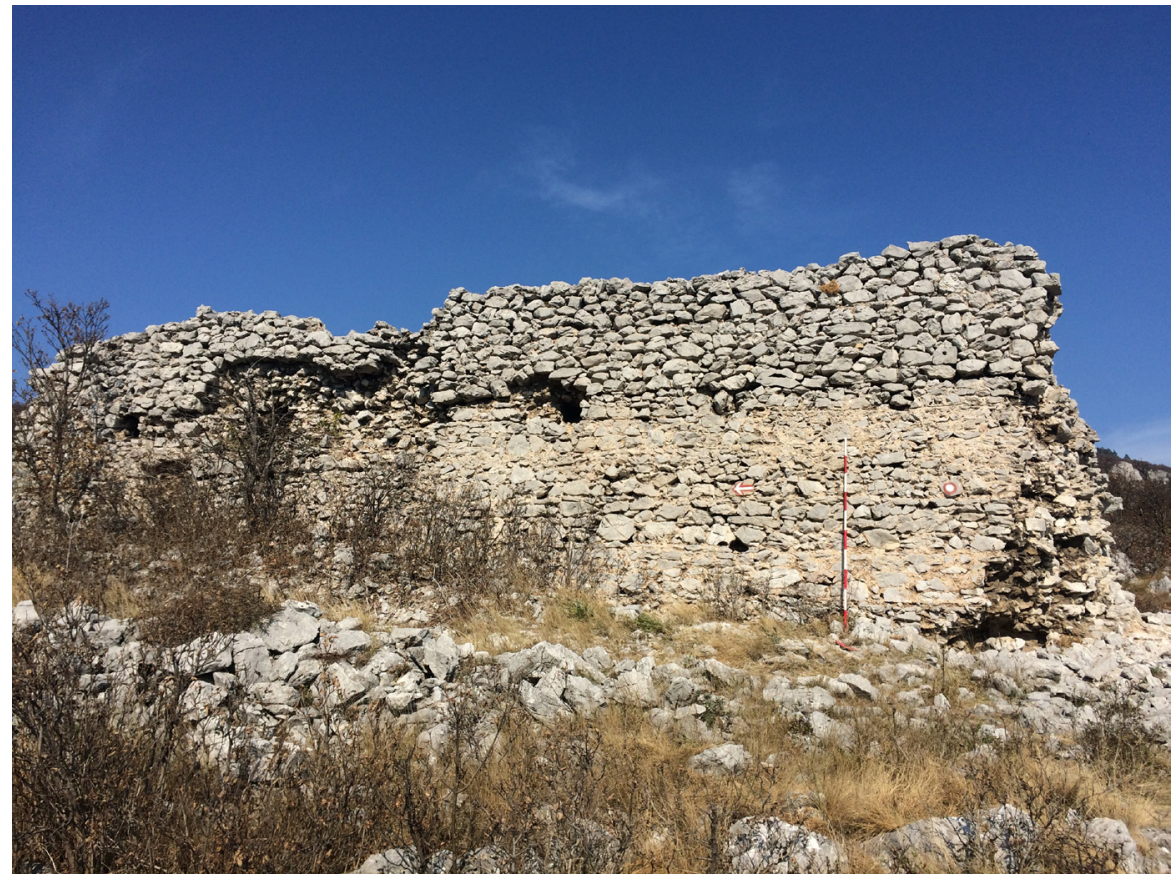

Сл. 10. Унутрашње лице северног зида утврђења (фото: М. Миловановић и И. Марјановић)

Fig. 10. The inner face of the northern wall of the fort (photo: M. Milovanović and I. Marjanović) 


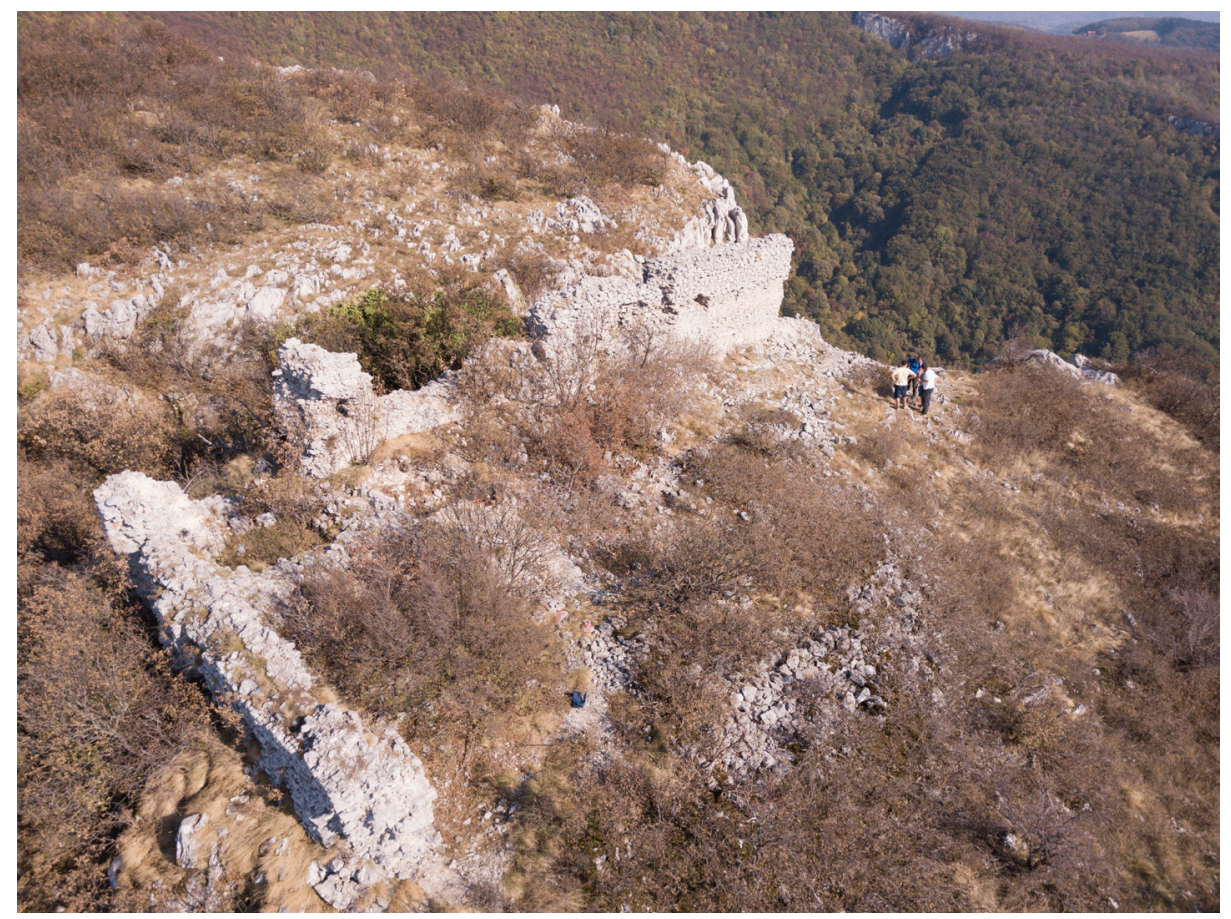

Сл. 11. Утврђење Шетаће, снимак из ваздуха (фото: И. Ајдачић)

Fig. 11. The fort of Šetaće, aerial shot (photo: I. Ajdačić)

планинарска стаза која води до врха поменуте планине, одакле се између литица и густе шуме кретање усмерава према остацима фортификација на локалитету Шетаће.

У северној зони стеновитог платоа изграђено је утврђење (сл. 11, 12). Данас су сачувани северни и западни одбрамбени зидови, начињени од ломљеног и притесаног камена мале и средње величине везаних кречним малтером. Ширина очуваних зидина износи 1,70 м. Везивна структура је беличаста, помешана са уситњеним комадима кречњака, каменчића и ситним зрнима туцане опеке. Треба споменути и жућкасти малтер нанесен подужно, на средини и доњој зони унутрашњег лица северног зида. Могуће је да овај нанос представља неку мању санацију утврђења.

Северни зид има дужину од 26,20 м, док је очувана висина 4,60 м. На спољашњој и унутрашњој страни зида распознају се шест већих отвора (око 25 х 20 цм) за греде, које су чиниле унутрашњу конструкцију. Унутрашњост северног зида садржала је трпанац и ретке комаде опеке дебљине 4 цм. Ова ситуација могла је бити забележена у западној зони северног одбрамбеног зида, чије је спољашње лице уништено приликом рада илегалних трагача. 


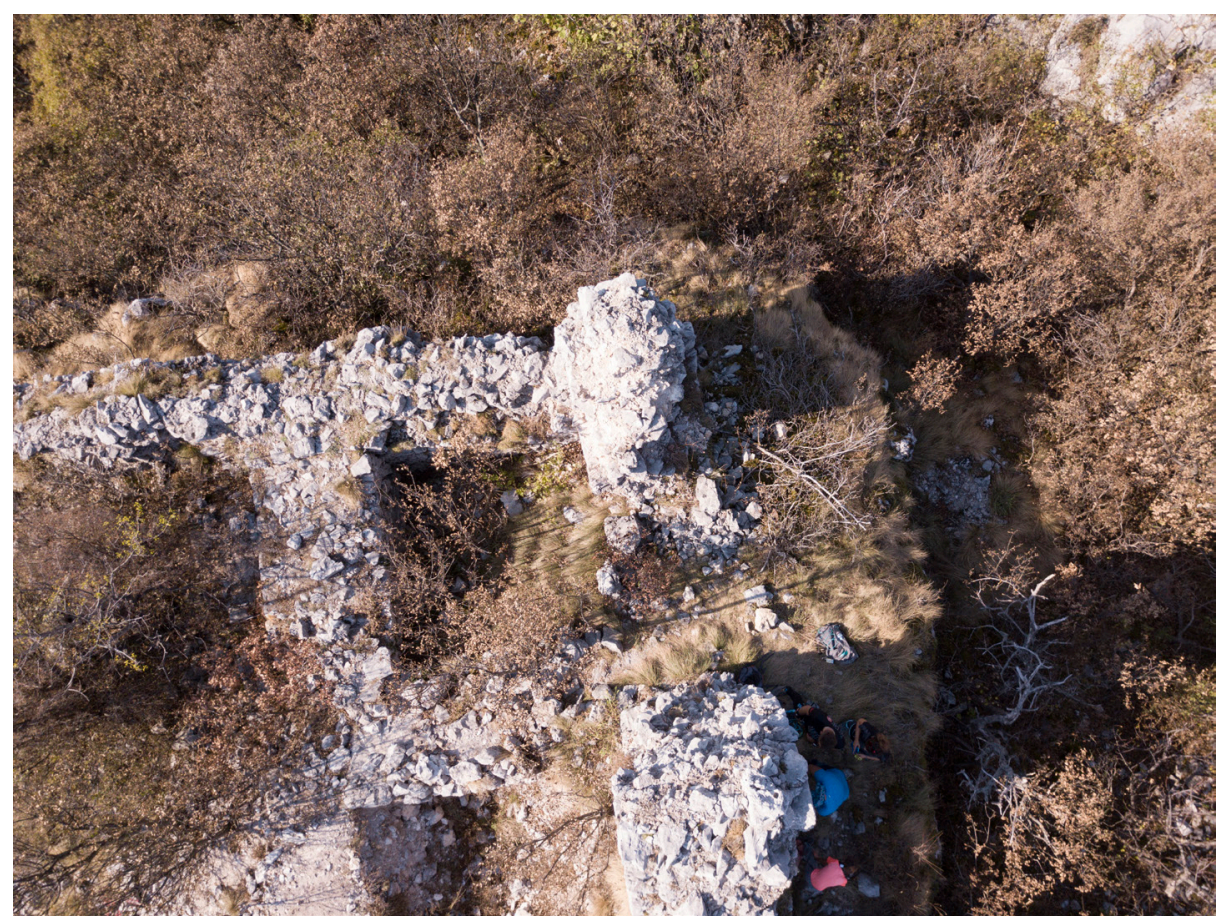

Сл. 12. Четвороугаона конструкција код споја северног и западног зида унутар утврђења, снимак из ваздуха (фото: И. Ајдачић)

Fig. 12. Quadrangular construction at the junction of the northern and western walls inside the fort, aerial shot (photo: I. Ajdačić)

Овде је здање претрпело највећу девастацију, која је видљива и на цртежу Николе Крстића (сл. 3, 12). Не треба искључити могућност да се овде можда налазио главни улаз у утврђење. У том случају је преко рова постојао дрвени мост који би водио унутар одбрамбеног простора. Нажалост, бочна лица претпостављеног улаза у оквиру северног зида, која би додатно потврдила ову претпоставку, нису забележена приликом обиласка. Оштећење је такође уочено и на средини унутрашњег лица и источној зони зида.

Паралелно са северним зидом налази се већ поменути ров, који је додатно бранио прилаз утврђењу од непријатељског напада. Његова дужина износи око 40 м, док ширина на његовој средини варира између 7 и 8 м. Ширина се према западном и источном крају повећава. ${ }^{5}$ Испуну рова данас чине земља, камење и растиње. Тренутна измерена дубина у средишњем делу је око 2 м. Ров усечен у стени евидентиран је на средњовековном утврђењу

\footnotetext{
${ }^{5}$ Терен је на крајевима рова нераван и приступ је ризичан, стога ширине у овом делу нису измерене.
} 
Островица код Рудника (Јовановић 1997, 531, сл. 10). Слична ситуација се наслућује и на оближњем локалитету Градац код Крепољина (Milovanović, Radisavljević and Filipović in print).

Западни бедем има дужину од 12,10 м, док је код споја са северним зидом измерена висина 3,50 м. Очувана висина на јужном крају износи 2,60 м. Требало би још једном напоменути да је Никола Крстић скицирао и слабије очувани јужни зид утврђења. Судећи према приложеној основи, тај зид је био у саставу са оним западним у оквиру његове јужне зоне. Приликом обиласка локалитета 2019. године нису забележени његови остаци. На том делу терена распознаје се агломерација камена средње и мале величине без видљивих наслага малтера. Њена оријентација је запад-исток.

Уз северни и западни одбрамбени зид подигунута је гређевина за коју не можемо са сигурношћу рећи да ли представља просторију или кулу. Реч је о мањој четвртастој конструкцији начињеној од ломљеног и притесаног камена мање величине са кречним беличастим малтером као везивним средством. Њене унутрашње димензије износе 2,80 х 2,70 м. Ширина јужног и источног зида грађевине износе 1,60, односно 1, 40 м. Назире се да њени зидови нису у конструктивној вези са зидовима утврђења, што указује на фазе градитељских активности. Ипак, за доношење коначног суда о евентуалним фазама градње мора се сачекати реализација археолошких ископавања. Такође треба поменути мањи део очуваног источног зида, који се простирао даље према југу, што упућује на још једну грађевину у овом делу брањеног ареала. Овај зид је претрпео оштећење и не може се рећи ништа о његовим основним карактеристикама.

Судећи према скици Николе Крстића, источно од гореописане конструкције налазила се већа правоугаона грађевина, која се до данас није сачувала. На овом месту данас се уочава разбацана земља, ретко растиње и ломљено камење мале и средње величине, са примесама кречног малтера.

Јужна страна одбрамбеног простора прекривена је вегетацијом. У овом делу брањеног ареала није било могуће уочити остатке архитектуре. На површини терена, аутори ових редова су од покретних археолошких налаза пронашли мањи број атипичних уломака седре и опеке.

\section{Закључак}

Теренски обилазак локалитета Шетаће имао је за циљ да региструје степен очуваности утврђења. Остаци фортификација испод планинског врха Мали Вукан били су током друге половине 19. века у неколико наврата предмет интересовања путописаца и истраживача (сл. 13). Тако је Јован 


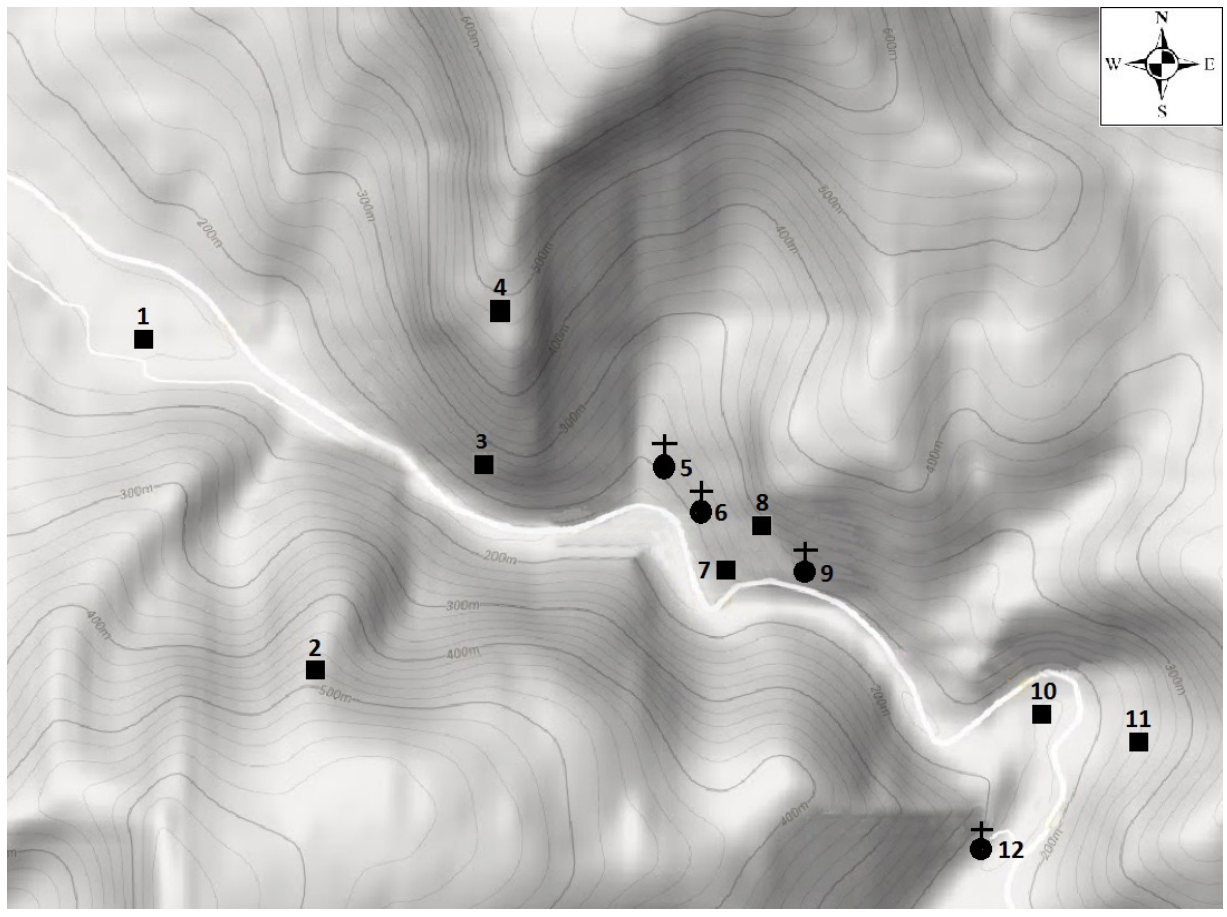

Сл. 13. Приближна распрострањеност фортификација и сакралних споменика у Горњачкој клисури: 1. Кула поред пута Петровац-Жагубица уз десну обалу Млаве; 2. Кула на врху Досу Мик на Јежевцу; 3. „Велика Пећина” испод локалитета Шетаће; 4. Шетаће; 5. Митрополија; 6. Мала црква Богородице Пречисте; 7. Узенгије; 8. Јеринина кула; 9. Комплекс Цркве Благовештења; 10. Грац - Горњачки извор; 11. Стража - Чока попи; 12. Манастир Горњак (map: google terrain hybrid)

Fig. 13. Approximate distribution of fortifications and sacral monuments in the Gornjačka Klisura gorge: 1. The tower near the Petrovac-Žagubica road, along the right bank of the Mlava River; 2. The tower at the peak of Dosu Mik on the Ježevac Mountain; 3. "Velika Pećina" below the site of Šetaće, 4. Šetaće; 5. Mitropolija; 6. Small church of the Immaculate Mother of God; 7. Uzengije; 8. Jerina's Tower; 9. The Holy Annunciation church complex; 10. Grac - the spring of Gornjački Izvor, 11. Straža - Čoka Popi; 12. The monastery of Gornjak (map: Google Terrain Hybrid)

Драгашевић начинио скицу на којој је утврђење хексагоналне основе. ${ }^{6}$ Уз $_{3}$ велику резерву можемо претпоставити да је тада забележио боље очуване остатке зидина, које су до данас ишчезле. Друга, вероватнија могућност јесте да је српски географ сагледао зидине издалека, па их је на приложеној скици само позиционирао као војно утврђење. На то би могла да указује чињеница да на цртежу није приказан ров.

${ }^{6}$ Гласник Српског ученог друштва, књ. XLIII (1876), стр. 312. 
Најзначајније податке о локалитету Шетаће оставио је Никола Крстић током педесетих година 20. века. Његове основе и скице се у великој мери поклапају са ситуацијом на терену. У северној зони стеновитог платоа данас су видиљиви остаци северног и западног одбрамбеног зида, који су међусобно спојени. Између њих, са унутрашње стране распознају се грађевине. Слабо очувани јужни зид, који је назначио Никола Крстић (Јацановић, Живковић 2000, 147, T. VII), упућује на претпоставку да је можда овде реч о мањем утврђењу правоугаоне основе. Паралелно са северним зидом налази се ров у дужини од око 40 м, који свакако сугерише на чињеницу да је овај простор био брањен по јасно утврђеном плану.

Зидине утврђења су начињене од ломљеног и притесаног камена који је везан беличастим малтером, помешаним са ситним ломљеним кречњаком, каменчићима и уситњеним комадићима опеке. Вредно је истаћи да је таква техника зидања забележена на северном утврђеном зиду на локалитету Узенгије изнад десне обале Млаве. На том месту се налази сложен утврђени систем, који, као што је већ истакнуто, у науци није у довољној мери представљен, упркос обиласцима терена.

Идентична техника зидања прелиминарно наговештава да су фортификације на археолошким локалитетима Шетаће и Узенгије грађене у исто време. Међутим, када се то догодило, засад је тешко рећи без стручних архолошких ископавања. Приликом обиласка ових утврђења током 2019. године нису пронађени хронолошки осетљиви покретни археолошки налази који би бар наговестили могуће датовање констатованих бедема. Судећи према информацијама које нам доставља Драган Јацановић, на локалитету Шетаће случајно су откривени предмети који се опредељују у време 4-6. века (Јацановић 2013, 13-14). Истраживања показују да је градња утврђених насеља на тешко приступачним местима током рановизантијског периода уобичајена појава (Милинковић 2010, 222). Условно речено, терен на коме се налазе остаци фортификација испод Малог Вукана може сугерисати насељавање током овог раздобља историје (Миловановић 2016б, 43). Одбрана је замишљена најпре избором висинског, природно заштићеног положаја, који је условио неправилну основу прилагођену конфигурацији стеновитог терена. Због све чешћих варварских напада, утврђења су грађена са јасним циљем да приступ буде доступан само с једне стране, док би стрме литице и падине онемогућавале прилаз из других праваца (Милинковић 2015, 49-50, 55). Очигледно је реч о траговима вертикалне миграције између 4-6. столећа, који су, судећи према досадашњим истраживањима, констатовани на простору Браничева (уп. Миловановић 2016а, 109-110, 119-121, 122-136, 
137-145; Мишић и Селаковић 2017, 19; Миловановић 2017; Миловановић и Филиповић 2018; Миловановић 2018; Milovanović 2019; Миловановић 2019, 307; Milovanović, Radisavljević and Filipović in print).

На основу аналогија којима уз нужни опрез располажемо, чини се да су зидине испод Малог Вукана можда подигнуте током средњег века.? Паралеле проналазимо на висинском локалитету Град-Чрнче код Скопља у Северној Македонији. Основа дворца (22,50 х 12 м) која је ту истражена има појединих сличности са очуваном архитектуром на Шетаћу. Реч је о дворском комплексу правоугаоне основе који је подигнут унутар брањеног ареала на тешко приступачном гребену, највероватније током 11-12. века. Његова унутрашњост је подељена на четири одељења неједнаких димензија. Судећи према речима Ивана Микулчића, током археолошких ископавања установљено је да се испод дворског комплекса налази грађевина из 6. века (Микулчиќ 1982, 129-133, сл. 72-73). Ипак, засад је још увек рано говорити о томе да ли је испод Малог Вукана изграђен утврђени двор између 11-12. века, односно у време када је обновљена византијска власт на Балкану (Острогорски 1959, 296, 300, 317, 356, 380; Динић 1958, 14; Станковић 2014, 283, 288-289).

У историјској науци је прихваћено да остаци фортификација у Горњачкој клисури представљају упоришта полубраће Дрмана и Куделина. Александар Узелац оправдано сматра да су полубраћа имала на располагању руднике у североисточној Србији (Узелац 2015, 206-207), од којих су неки споменути у овом раду. Сам податак који наводи Данило II, да су Дрман и Куделин „сакупили око себе многу војску народа татарскога и Кумене, давши им много злата" (Даничић 1866, 115), сведочи о њиховој економској моћи, као и на могућу експлоатацију оближњих рудника у којима је сасвим извесно постојала руда овог племенитог метала (Узелац 2015, 207; Simić 1951, 243244, 249; Ћирковић, Ковачевић-Којић и Ћук 2002, 53). У том случају може се претпоставити да су бугарски и татарски моћници располагали материјалним средствима захваљујући којима су могли да предузму изградњу одбрамбених зидина у Горњачкој клисури. Међутим, да ли су полубраћа обновила већ постојеће утврђење или су саградила ново (што је мање вероватно), не може се тачно рећи. У сваком случају, као закључак се намеће да су фортификације на локалитету Шетаће подигнуте на стратешки вешто одабраном месту будући да су житељи могли да контролишу продор са запада, одакле је претила највећа опасност. Ако се претпостави да је правоугаоно утврђење

\footnotetext{
${ }^{7}$ Градња утврђења, додуше већих димензија, на стеновитим висинским позицијама забележена је током средњовековне епохе, а као пример се могу навести Островица код Рудника (Јовановић 1997) или Ужички град (Ророvić 1995).
} 
испод Малог Вукана било у употреби када су Дрман и Куделин господарили Браничевом и околином, онда је њихова војска са тог места сасвим извесно контролисала нападе Угара и Срба током последње четвртине 13. века.

Не треба искључити могућност градитељске активности у време српске власти. Основано се сматра да су Немањићи зидали утврђења у земљи Браничево након што су је освојили и припојили држави највероватније након 1284. године (Станковић 2012, 85-86). ${ }^{8}$ Судећи према досадашњим истраживањима, такав је случај са Голубачком тврђавом (Симић 2012, 53). Фазе градње на утврђењу испод Малог Вукана данас се само назиру на споју јужног зида гређевине и унутрашњег лица западног одбрамбеног зида утврђења. Да ли су оне заиста постојале, и када су настале, остаје отворено питање док се не спроведу археолошка ископавања. Треба поменути и кречни малтер жућкасте боје, који сугерише санацију унутрашњег лица северног зида, али је тешко рећи када се она догодила.

Можда је корисно споменути фазе градитељских активности на локалитету Узенгије које су поуздано евидентиране на споју северног и источног зида утврђења одмах испод далековода. Приликом краћег обиласка терена, уочено је да ова два зида нису у конструктивној вези. На закључак о фазама градње додатно наводи и коришћење другачијег малтера на источном зиду утврђења, у чијој смеси нема ситног ломљеног кречњака и уситњене опеке. Поред тога, ширина ових зидина није уједначена. Измерена ширина на севером зиду је 1,20 м. Источни зид је у горњој зони 1,50 м, док је у доњој и до 2 м широк. Не треба искључити могућност градитељских подухвата, свакако у виду обнове, у време када су ови крајеви били под турском влашћу. У науци је прихваћено да су тврђаву Ждрело разориле Османлије 1458. године (Вушковић 2010, 108). Међутим, треба напоменути да је ареал тврђаве на десној обали Млаве био активан и током наредних деценија 15. века, када су нови господари зидали профане објекте (Кнежевић 1988, 200-201). Током устанка Срба у време Дугог рата (1593-1606) захваћен је и простор јужно од Дунава и Саве. Историјски подаци указују да се побуна спустила до Ждрела у Млави (Веселиновић 1981, 444).

Судећи према досадашњим испитивањима терена, још увек је рано доносити коначне закључке о локалитету Шетаће у Горњачкој клисури. Први писани извори у којима се спомиње тврђава Ждрело јављају се 1324.

\footnotetext{
${ }^{8}$ Када је реч о години сукоба и припајању Браничева Драгутиновој држави, у науци постоје и друга мишљења. У старијој литератури је одређена 1291. година када Браничево пада у Драгутинове руке (Динић 1958,19$)$, и она се дуго у историјској науци сматрала одрживом, УП. Максимовић 1981, 442-443, нап. 26; Мишић 2006, 11; Миљковић и Крстић 2007, 82-83. У новијим истраживањима, сукоби се везују за 1292. годину (Узелац 2015, 210).
} 
године (Даничић 1866, 115; Мак Даниел 1991, 220). Новије историјске интерпретације не пружају довољно убедљивих података и доказа о времену њеног настанка (уп. Вушковић 2008; Мишић 2006, 11; Миљковић и Крстић 2007, 82-85; Миљковић и Крстић 2008, 283; Вушковић 2010, 107-108; Мишић и Селаковић 2017, 17-18, нап. 18). Видљиви остаци фортификација изнад леве и десне обале Млаве у Горњачкој клисури наговештавају да се ради о једном ширем утврђеном комплексу. Питање које се намеће јесте: да ли су остаци одбрамбених зидина испод Малог Вукана представљени у овом раду били у саставу утврђеног комплекса Ждрела и на који начин? У том смислу, одговор, али и нова сазнања о фортификацијама у клисури Млаве могу да пруже само стручна археолошка ископавања, за која верујемо да ће ускоро и уследити.

\section{БИБЛИОГРАФИЈА}

Бошковић, Ђ. 1950. Средњовековни споменици североисточне Србије, Старинар I, 185-202.

Благојевић, М. 1987. Преглед историјске географије средњовековне Србије, Зборник Историјског музеја Србије 20, Београд, 45-126.

Vasić, M. i Milošević, G. 2000. Mansio Idimvm. Rimska poštanska i putna stanica kod Medveđe, Beograd: Arheološki institut.

Веселиновић, Р. 1981. Срби у Хрватској у XVI и XVII веку, у Историја српског народа III-1, Срби под туђинском влашћу (1537-1699), ур. Р. Самарџић, Београд: Српска књижевна задруга: 427-451.

Веселић, J. 1867. Описъ монастира у Србіи, Частъ I, Београд: Кньигонечатия А. Андрића.

Влаић, Т. 1850. Србскіѝ венацъъ, одь народиьи србскійисторическиинаравоучителиьь прича, песама, басна, пословища и загонетки исплетень, I часть, Београд: Печатано у Кньигопечатньи Кивжества Српскогь.

Вушковић, М. 2010. Ждрело, у Ј. Мргић, ур. Лексикон градова и тргова средњовековних српских земаља према писаним изворима, Београд: Завод за уџбенике, 107-108.

Вушковић, М. 2008. Средњовековни град Ждрело, Весник Војног музеја 35, 133 136.

Даничић, Ђ. прир. 1866. Животи краљева и архиепископа српских, написао архиепископ Данило и други, Загреб: У Светозара Галца у ком.

Динић, М. 1958. Браничево у средњем веку, Пожаревац: Народни универзитет у Пожаревцу.

Драгашевић, J. 1876. Принос за географију Србије. Млава и Пек. С картом Хомоља, Гласник Српског ученог друштва, књ. XLIII, Београд, 261-346. 
Dragojević, Č. 1983. Muzej u Požarevcu. Istorijat. Današnje stanje i perspektiva razvoja, Magistarski rad, Sveučilište u Zagrebu, Centar za postdiplomski studij.

Јацановић, Д. и Живковић, Ј. 2000. Археолошке „белешке” Николе Крстића, Viminacivm 11, 111-154.

Јацановић, Д. 2013. Касноантичка налазишта у Браничеву, у Од Романа до Словена. Археолошки налази из Србије и њихов контекст, Научни скуп у организацији Филозофског факултета у Београду, ур. М. Милинковић, (књига апстракта радова са програмом скупа), 12-13. децембар, Београд: Филозофски факултет у Београду, 13-14.

Јиречек, К. 1959. Војна цеста од Београда за Цариград и балкански кланци, у М. Динић, ур. Зборник Константина Јиречека 1, Посебна издања 326, Одељење друштвених наука, књ. 33 (н. с.), Београд: Научно дело, 71-191.

Јовановић, В. 1997. Островица код Рудника. Прилог проучавању средњовековних градова у Србији, у М. Лазић, ур. Уздарје Драгославу Срејовићу. Поводом шездесетпет година живота од пријатеља, сарадника и ученика, Београд, 513-526.

Јовановић, Љ. 1903. Млава. Антропогеографска проучавања Љубомира Јовановића, Насеља српских земаља - расправе и грађа, књига II, Српски етнографски зборник V, Београд, 247-457.

Јовић, В. 1997. Геолошке и геоморфолошке карактеристике Источне Србије, у Археологија источне Србије, Научни скуп Археологија источне Србије, Београд Доњи Милановац, децембар 1995, ур. М. Лазић, Центар за археолошка истраживања 18, Београд: Филозофски факултет, 21-31.

Карић, В. 1887. Србија - опис земље, народа и државе, Београд: Краљевско-српска државна штампарија.

Кнежевић, Б. 1988. Манастири у Браничеву према турском попису из 1467. године, Саопитењ а XX-XXI, 197-209.

Мадас, Д. и Гајић, А. 1983. Надгробне плоче и гробови ктитора цркве Богородице Пречисте у комплексу Ждрела у Горњачкој клисури, Саопштења XV, Београд, 221-242.

Мадас, Д. 1997. Ждрело - средњовековно утврђење, религијско и култно средиште Млаве, у Археологија источне Србије, Научни скуп Археологија источне Србије, Београд - Доњи Милановац, децембар 1995, ур. М. Лазић, Центар за археолошка истраживања 18, Београд: Филозофски факултет, 313-317.

Мак Даниел, Л. К. 1991. Генезис и састављање Даниловог зборника, у Архиепископ Данило II и юегово доба. Међународни научни скуп поводом 650 година од смрти, САНУ, Научни скупови, књ. LVIII, Одељење историјских наука, књ. 17, ур. В. Ђурић, Београд, 217-224.

Максимовић, Љ. 1981. Почеци освајачке политике, у Истроија српског народа I, Од најстаријих времена до Маричке битке (1371), ур. С. Ћирковић, Београд: Српска књижевна задруга: Београд, 437-448.

Марковић, J. 1988. Енциклопедијски географски лексикон Југославије, Сарајево: SUOR Svjetlost Sarajevo. 
Микулчиќ, И. 1982. Старо Скопје со околните тврдини, Скопје: Македонска книга. Милићевић, М. 1876. Кнежевина Србија, Београд: Државна штампарија.

Милинковић, М. 2010. Градина на Јелици. Рановизантијски град и средњовековно насеље, Београд: Завод за уџбенике.

Милинковић, М. 2015. Рановизантијска насеља у Србији и њеном окружеюу, Београд: Досије студио.

Миловановић, М. 2016а. Браничево у рановизантијском периоду на основу археолошких налаза, Мастер рад, Филозофски факултет, Универзитет у Београду.

Миловановић, М. 2016б. Рановизантијски локалитети у Хомољу, Хабилитациони рад, Народни музеј Београд.

Миловановић, М. 2017. Рановизантијски локалитети у околини Жагубице, Браничевски гласник 11, 29-46.

Миловановић, М. 2018. Рановизантијски локалитет Пчелињи крш (Крш ку албина) у Лазници код Жагубице, у Рановизантијски период у околини Жагубице. Преглед археолошких налаза, ур. М. Миловановић и О. Филиповић, Жагубица: Завичајни музеј Хомоља у Жагубици, 7-10.

Миловановић, М. и Филиповић, О. 2018. Рановизантијски период у околини Жагубице и смернице ка даљим истраживањима, у Рановизантијски период у околини Жагубице. Преглед археолошких налаза, ур. М. Миловановић и О. Филиповић, Жагубица: Завичајни музеј Хомоља, 2-6.

Milovanović, M. 2019. Archeological Site Grac - Gornjak spring in Gornjak Gorge, Archaeology and Science 15, 53-70.

Миловановић, М. (у штампи) Историјат истраживања археолошких налазишта и средњовековних црквених споменика у Хомољу, Хомољски зборник 1, Жагубица: Завичајни музеј Хомоља у Жагубици.

Milovanović, M., Radisavljević D. and Filipović, O. (in print) Archeological Site Gradac near Krepoljin in Homolje, Archaeology and Science 16.

Миљковић, Е. и Крстић, А. 2007. Браничево у XV веку. Историјско-географска студија, Пожаревац: Народни музеј Пожаревац.

Миљковић, Е. и Крстић А. 2008. На раскршћу две епохе: континуитет и промене друштвене структуре у Браничеву у 15. веку, Историјски часопис, LVI, 279-304.

Мирковић, М. 1981. Економско-социјални развој у II и III веку, у Истроија српског народа I, Од најстаријих времена до Маричке битке (1371), ур. С. Ћирковић, Београд: Српска књижевна задруга: Београд, 77-88.

Мишић, С. 2006. Територијална организација Браничева (XII-XV век), Браничево кроз војну и културну историју Србије I, Свеска 3, Пожаревац, 11-18.

Мишић, С. и Селаковић, М. 2017. Средњовековно наслеђе на тлу Хомоља, Браничевски гласник 11, 17-25.

Мркобрад, Д. 1997. Средњовековно рударство на простору Источне Србије, у Археологија Источне Србије, Научни скуп Археологија источне Србије, Београд - Доњи Милановац, децембар 1995, ур. М. Лазић, Центар за археолошка истраживања 18, Београд: Филозофски факултет, 151-161. 
Острогорски, Г. 1959. Историја Византије, Београд: Просвета.

Петковић, В. 1935. Геологија Источне Србије, Српска краљевска академија, Посебна издања, књига 1, Београд: Задужбина Каменка и Павла Браће Јовановића 9.

Пирх, О. Ф. Д. 1900. Путовање по Србији у години 1829, Српски превод од Д. Т. Мијушковића, Београд: Академија наука.

Поповић, К. 1867. Пут лицејских питомаца (јестаственичког одељења) по Србији године 1863, Београд: Државна штампарија.

Popović, M. 1995. Užički grad, Beograd, Užice: Arheološki institut, Istorijski arhiv.

Симић, Г. 2012. Средюовековни град Голубаи, Београд: Републички завод за заштиту споменика културе.

Simić, V. 1951. Istorijski razvoj našeg rudarstva, Beograd: Izdavačko-štamparsko preduzeće Saveta za energetiku i ekstraktivnu industriju Vlade FNRJ.

Станковић, В. 2012. Краљ Милутин (1282-1321), Београд: Фреска.

Станковић, В. 2014. Путовања кроз Византију, Београд: ЈП Службени гласник.

Ћирковић, С. 1981. Срби у одбрани угарских граница, у Историја српског народа II, Доба борби за очување и обнову државе (1371-1537), ур. J. Калић, Београд: Српска књижевна задруга: 465-478.

Ћирковић, С., Ковачевић-Којић, Д. и Ћук, Р. 2002. Старо српско рударство, Београд, Нови Сад: Вукова задужбина, Прометеј.

Узелац, А. 2015. Под сенком пса. Татари и јужнословенске земље у другој половини ХІІІ века, Београд: Утопија.

Узелац, А. 2018. Крсташи и Срби (XI-XII век), Београд: Утопија.

Flora, R. 1952. Dictionar sârb - român. Српско-румунски речник, Varșeț: Frăție Unitate.

Хердер, Б. Ж. А. В. 1845. Рударскь путь по Сербли. 1835. год. У изводу, Београд: Кньигопечатньи Княжеско - Србской.

Цуњак, М. и Миљковић, М. 1992. Горњачко-рибарска клисура у светлу археолошких истраживања, Гласник друштва конзерватора Србије 16, 101-104.

Цуњак, М. и Миљковић, М. 1993. Градац код Крепољина у светлу заштитних истраживања, Гласник друштва конзерватора Србије 17, Београд, 67-69.

Шкриванић, Г. 1974. Путеви у средюовековној Србији, Београд: Новинско-издавачко предузеће „Туристичка штампа”. 


\title{
Milan B. Milovanović
}

Požarevac

\section{Ivan R. Marjanović}

Požarevac

\section{ARCHAEOLOGICAL SITE OF ŠETAĆE ON THE MOUNTAIN OF MALI VUKAN IN THE GORNJAČKA KLISURA GORGE}

\author{
Keywords: Gornjačka Klisura, Šetaće, Mali Vukan, defensive wall, \\ Ždrelo, Nikola Krstić, fortification
}

This paper presents the results of a survey of the archaeological site of Šetaće, located on the mountain of Mali Vukan in the Gornjačka Klisura gorge, above the right bank of the Mlava River. The authors of the paper performed a field survey in October 2019. At present, the remains of a fort and a trench can be recognized very well on the site. According to past researches, little attention has been paid by science to this part of the Gornjačka Klisura. The first interest in the fort below Mali Vukan was recorded in 1863 by the Lyceum cadets from Belgrade. A more detailed description of the situation in the field came during the 1950s from Nikola Krstić, an antique enthusiast from Petrovac na Mlavi and a former associate of the National Museum in Požarevac. After his amateur examinations of the Gornjačka Gorge, fortifications above the right and the left bank of the Mlava River became the subject of brief reconnaissance surveys by the Cultural Monument Protection Institute from Kragujevac, Regional Institute for Protection of Cultural Monuments from Smederevo, Institute for the Protection of Cultural Monuments of Serbia from Belgrade and National Museum in Požarevac. The paper presents the current state of fortifications at the site of Šetace with a brief overview of the defensive architecture located in the Gornjačka Klisura. According to the current state, there are remnants of the northern and western defensive walls on the rocky plateau below Mali Vukan. At their junction, on the inner side, a rectangle based structure, filled with earth and rubble, can be noted. A cut in the rock - a trench, which additionally defended the fort from the northern side, extends in parallel to the northern defensive wall. No mobile archaeological findings were discovered during the survey that would indicate a possible inhabitation of the site in the past. The aim of this paper is to get the public acquainted with the fortifications below Mali Vukan in order to provide guidance for further archaeological research with the primary purpose of uncovering the time of construction of the fort at the site of Šetaće. 